\title{
The Analysis Of Moral Value And Character In Novel "Negeri 5 Menara" By Ahmad Fuadi
}

\author{
${ }^{1} \mathrm{M}$. ASRUL HASBY, ${ }^{2}$ M. JAGAT ISLAMI \\ ${ }^{12}$ Universitas Pendidikan Mandalika, Jl. Pemuda No. 59A, Dasan Agung Baru, kec. Mataram, Nusa \\ Tenggara Barat. 83125 \\ E-mail: Muhammadasrulhasby@gmail.com, m.jagatislami@gmail.com
}

\begin{abstract}
This research is descriptive method. By employing descriptive method, this research was trying to present an analysis of moral value and character in novel Negeri 5 Menara novel by Ahmad Fuadi. Most of the data taken from books and internet references. It aims at finding out the differences between the major character and the minor character and the moral value. This study is structural analysis by employing descriptive method approach. This research is expected to be able to identify the specific differences between the major character and the minor character and the moral value. Hopefully the writer is able to identify some differences of the major and minor characters and find the moral value of the novel. As the result of this research we can identify some character differences. In factual, the major character and the minor character are found in Negeri 5 Menara novel, but they have some differences themselves. And also the moral value is found. There were six major characters as the protagonist that were grouped into "Sahibul Menara". They were Alif Fikri, Raja Lubis, Said Jufri, Dulmajid, Atang Yunus, and Baso Salahuddin. The other characters in the novel were minor characters, such as Ayah, Amak, Kiai Rais, Ustad Salman, and Tyson. The differences between the major characters and the minor characters in the novel were the major characters that took some important role in the story and the minor characters who did not take important role. The minor characters appeared only to support the major characters even though the minor characters showed up some times. The moral values which could be taken from the novel "Negeri 5 Menara" were sincerity, patience, honesty, and leadership as characterized in the novel. Finally the writer suggests to readers especially English literature students to conduct more research for understanding the analysis of protagonist character.
\end{abstract}

\section{Key words : Moral Value, Character}

\begin{abstract}
Abstrak. Penelitian ini adalah metode deskriptif. Dengan menggunakan metode deskriptif, penelitian ini mencoba menyajikan analisis nilai moral dan karakter dalam novel Negeri 5 Menara karya Ahmad Fuadi. Sebagian besar data diambil dari buku dan referensi internet. Ini bertujuan untuk mengetahui perbedaan antara karakter utama dan karakter minor dan nilai moral. Penelitian ini adalah analisis struktural dengan menggunakan pendekatan metode deskriptif. Penelitian ini diharapkan dapat mengidentifikasi perbedaan spesifik antara karakter utama dan karakter minor dan nilai moral. Semoga penulis mampu mengidentifikasi beberapa perbedaan karakter utama dan minor serta menemukan nilai moral novel tersebut. Sebagai hasil dari penelitian ini kita dapat mengidentifikasi beberapa perbedaan karakter. Faktanya, karakter utama dan karakter minor ditemukan dalam novel Negeri 5 Menara, tetapi mereka memiliki beberapa perbedaan sendiri. Dan juga nilai moral ditemukan. Ada enam karakter utama sebagai protagonis yang dikelompokkan menjadi "Sahibul Menara". Mereka adalah Alif Fikri, Raja Lubis, Said Jufri, Dulmajid, Atang Yunus, dan Baso Salahuddin. Karakter lain dalam novel adalah karakter minor, seperti Ayah, Amak, Kiai Rais, Ustad Salman, dan Tyson. Perbedaan antara karakter utama dan karakter minor dalam novel adalah karakter utama yang mengambil peran penting dalam cerita dan karakter minor yang tidak mengambil peran penting. Karakter minor muncul hanya untuk mendukung karakter utama meskipun karakter minor muncul beberapa kali. Nilai-nilai moral yang dapat diambil dari novel "Negeri 5 Menara" adalah ketulusan, kesabaran, kejujuran, dan kepemimpinan sebagaimana
\end{abstract}


dicirikan dalam novel. Akhirnya penulis menyarankan kepada pembaca terutama siswa sastra Inggris untuk melakukan lebih banyak penelitian untuk memahami analisis karakter protagonis.

Kata kunci: nilai moral, karakter

\section{BACKGROUND}

Literature is a way of communication which is very important in our social life. It is expressed in the very specific ways. The readers are very interested in

reading because besides getting information, they can enjoy pleasure of reading to get the information means reading for outcome. It fulfills the aims of reading literature (Hidayat, S. 2010: 2).

Literature is a form of art because we can enjoy the beauty through language. Halim wrote that:

Literature is not a science but art. Most art activities involve a log of emotional aspects of man kinds, such as: feeling, spirit belief and others are difficult to define. Although it is hard to define, basically, literature is a language art (Halim, 2003:35).

When we are talking about literary work, it is clear in our mind that literary work is meant of convey message by using language but it is quite different from ordinary language because literature has its own way or right in using language.

Lombardi (1996: 29), defines literature: "A shifting category of text defined by a complex combination of factors including textual features and value

judgments". Literature is language that portrays certain qualities. These qualities are: an impact on the audience, a good use of the resource of language and the style used by author, such us poem, novel, letter, and art. In any form it will have an impact on the reader and will often shape or change the reader's views on areas of human life. There of the main areas which literature will effect are the religious, social, personals views of the reader (Hikmawati. R, 2005: 1).

There are some kinds of literary work, novel is one of them. Novel becomes very popular among the readers. The writer of literary works expresses their experience, feeling, thought, idea, etc by imagination. Negeri 5 Menara novel by Ahmad fuadi is popular and best sellers novel in Indonesia. This novel tells a young boy, Alif. He is from small village in Sumatra. Alif was born on the edge of Lake Maninjau and never touched the ground outside the realm of Minangkabau but suddenly he had to take a bus three days and three nights across the back of Sumatra and Java into a remote village in East Java for learning in the lodge (Negeri 5 Menara nove 2009).

In Negeri 5 Menara novel, there are two kinds of characters that show up in the novel. They are major and minor character. The major is the main character of a story and also dominate the whole of story. The minor is the characters that supporting the major character, minor characters are often static show up in the novel (the writer, 2011).

Based on the background of Negeri 5 Menara, the writer is interested in investigating the difference of the major and minor character in novel, and also the writer concerns to describe moral value in Negeri 5 Menara novel.

\section{A. Problem Statement}

Based on the background above, the writer would like to formulate the following research problems:

1. What is the moral value of this novel?

2. What is the difference of the major character and the minor character of this novel?

\section{LITERARY REVIEW}

\section{A. Previous Finding}

Novel is one away of conveying feeling and thought or a medium that can be used to criticize everything happens in this world where someone lives. Besides that, it also has certain elements that build it to be interesting and enjoyable thing to be read. And related to analysis of protagonist character, there are two researchers who have talked about it.

Rahma Eka Saputri Muin (2009) wrote "A Study of Lord Voldemort: An Antagonist Character in Harry Potter Novel". Her study analyzed about an antagonist character in Harry Potter novel. She described 
that Lord Voldemort is a protagonist character. It was also told

Lord Voldemortes sife and behaviors in Harry Potter novel.

Supriadi Hidayat (2010) wrote "Power and Love in The True Story of Rebel Daughters by Janet Todd". Hidayat discussed the heroes and heroines of the novels and looked at how they all seemed molded from the same characters, males and females victim who survived to find love. The aim of this thesis is find out the differences of the major character and the minor character and the moral value covered in Negeri 5 Menara novel by Ahmad Fuadi. The method of this research is structural analysis. Based on the explanations above, the writer finds that a analysis of factor influencing protagonist character by using structural analysis approach can make easy to find out the protagonist character in the novel.

\section{B. Genre of novel}

There are many variables of the novel. Kennedy in Halim $(2007,195)$ divide novel into three classification of novel namely:

1. The historical novel

2. The apprenticeship novel

3. The picaresque novel

\section{Function of novel}

Novels as literary work have a function like the other literary work. According to Hoove (1980:195) described the function of novel which can be described as follows:

1. As an expression of an interpretation of life entertainer or escape.

2. As propaganda.

3. As an agent of change in the language and though of a culture.

4. As creator of life style and an arbiter of taste.

\section{Structure of novel}

A novel has structure such as: theme, plot, setting, point of view and character. Those structures will be explained more detail in this part.

\section{Theme.}

Theme of a novel is its underlying idea or "wisdom" that the author is presenting while according to Stanton and Kenny suggested that a theme is a meaning of a story. Someone should discover major conflict, considering both of them nearly relate to even they cannot separated one with another. (Edward and Jones Jr, 1968:82).

\section{Plot}

Plot is the plan, design, scheme, or pattern of event in a play, poem, or work of fiction; and furthers, the organization of incident and character in such a way as to induce curiosity and suspense in the spectator or reader. In simple word,

plot is the events in the story of a film, novel, short story, etc. (Cuddon 1998:513).

\section{Setting}

Setting in a dictionary of literary terms and literary theory, setting is the where and when of a story or play; the localy. In the drama term may refer to the scenery or props (Cuddon 1998:620).

\section{Point of view}

Point of view in a novel, is about who tells the story, form what position this actor and action can be seen. Point of view is the way an author permits us to observe the story and it can be a first person, third person, dramatic or omniscient

(Edwar H and Jones Jr, 1968:82). From point of view, the reader can know what the position of the storyteller is.

\section{Character}

Character in Mastering English Literature that was written by Richard Gill, character is someone in literary work who has some sort of identity (it need not to be a strong one), an identity which is made up by appearance, conversation, action, name, and (possibly) thought going on in the head.

\section{METHODOLOGY OF RESEARCH}

\section{A. Method of Research}

This chapter discussed about the methodology that the writer used in this research. It explained about the general procedure in collecting and analyzing the data. In exploring this research the writer used descriptive method. Descriptive

method is conducted by describing character and then analyzing them. This chapter consisted of sources of data, instrument of 
research, procedure of data collection, technique of data analysis.

\section{B. Sources of Data}

The writer used sources of data. They are the primary and secondary data. The primary data are domain data resources that the writer used in completing this thesis. The secondary data are the data that supported domain data. The resources of data that the writer meant are:

1. The primary source of data is novel Negeri 5 Menara.

2. Secondary data are that referred and related to the topic, they were taken from literary. They are books, journal, thesis, and some materials from internet.

\section{Procedure of Data Collection}

The writer passes the steps below in order to collect data. These steps are:

1. The writer read and collected some books related to literatures to support the object that is analyzed.

2. The writer identified and underlined each sentence and quotations that are related to the topic of the research.

\section{E. Technique of Data Analysis}

The technique above is conducted by using the complete procedures as

follows:

1. The writer read the novel carefully. Through this way, the writer paid attention on the text and notes somewhat is important to character and moral value that appeared in the novel.

2. The writer read and collected some books related to literature to support the object that is analyzed.

3. Analyzing all of the data by using the collected data.

4. Presenting the analysis and the description of data.

\section{FINDING AND DISCUSSING}

\section{A. Findings}

In this section, the writer discussed the data that were found in the novel "Negeri 5 Menara" and made discussion from the found data. The data which were relevant to the problem statements above were about the major and minor characters, and the moral values contained in the novel.

\section{Major Characters}

Major Characters in novel "Negeri 5 Menara" are Alif Fikri, Raja Lubis, Said Jufri, Dulmajid, Atang Yunus, and Baso Salahuddin. They were united in a group called "Sahibul Menara". Therefore, the author of novel "Negeri 5 Menara"

used word "kami" which meant "us" to describe the major characters "Menara

Sahibul", although sometimes he used word "saya" or "aku" which meant "I" that referred to Alif Fikri.

\section{Minor Characters}

There were lots of minor characters in the novel "Negeri 5 Menara". However, to limit the wideness of the problem, the writer restricted to character "Ayah", "Amak", "Kiai Rais", "Ustad Salman", and "Tyson".

In this section, the authors discussed the linkages between the major characters with the minor one and to what extent the minor characters supported the major characters.

\section{B. Discussion}

After analyzing the data that were found in the novel "Negeri 5 Menara", the writer discussed the data by categorizing the major character as the protagonist because Sahibul Menara was showed more in the novel. And the writer made some conclusions from the findings.

\section{CONCLUSION AND SUGGESTION}

\section{A. Conclusion}

After analyzing the data, the writer finally made conclusions. In novel "Negeri 5 Menara", there were six major characters as the protagonist that were grouped into "Sahibul Menara". They were Alif Fikri, Raja Lubis, Said Jufri, Dulmajid, Atang Yunus, and Baso Salahuddin. The other characters in the novel were minor characters, such as Ayah, Amak, Kiai Rais, Ustad Salman, and Tyson. The differences between the major characters and the minor characters in the 
novel were the major characters that took some important role in the story and the minor characters who did not take important role. The minor characters appeared only to support the major characters even though the minor characters showed up

some times.

The moral values which could be taken from the novel "Negeri 5 Menara" were sincerity, patience, honesty, and leadership as characterized in the novel.

\section{B. Suggestion}

Remembering that literary work is rich with a lot of aspects, the writer hopes in the future particularly in faculty of culture, management, and business, English Departement ( Mandalika University) will have many more references in literary work for students who want to analyze a novel. The writer suggests in order that this thesis can be used as beneficial reference about social aspects and changes in Indonesia about Negeri 5 Menara novel for others especially for them who also want to analyze same object or novel. The writer also hopes the left aspects will be observed by the next researchers in order to enlarge this writing.

\section{BIBLIOGRAPHY}

Alimul Hidayat A.A., (2010). Metode Penelitian Kesehatan Paradigma Kuantitatif, Jakarta: Heath Books

Abdul, Halim. 2003. Analisis Investasi. Jakarta. Salemba Empat

Ahmadi, Mukhsin. 1990. Strategi Belajar Mengajar Keterampilan Berbahasa \& Apresiasi Sastra.

Malang: Yayasan Asih Asah Asuh.

Aminudin.1995.Stilistika,Pengantar

Memahami Bahasa dan Sastra.

Semarang:IKIP Semarang

Press.

. 1990. Pengembangan Penelitian

Kualitatif dalam Bidang Bahasa dan Sastra. Malang: Yayasan Asah Asih Asuh. Al Ma'ruf, Ali Imron. 2009. Stilistika Teori, Metode, dan Aplikasi Pengkajian Estetika Bahasa. Surakarta: Cakra Books.
2009. Kajian Stilistika Novel Trilogi Ronggeng Dukuh Paruk. Karya Ahmad Tohari:

Persepektif Kritik Holistik. Disertasi. Tidak diterbitkan. Perpustakan Universitas Sebelas Maret.

2012. Pembelajaran Sastra Apresiatif Dengan Metode Rekreasi Responsi, dan Redeskripsi. diakses tanggal 04 Juli 2013 pukul 19.00 WIB dalam http://aliimronalmakruf.blogsp ot.com/2011/04/kbk.html.

Chaer, Abdul. 2007. Kajian Bahasa. Jakarta: Rineka Citra. Chun-Huan. Feng. 2010. A Preliminary Study on Stylistic Features of The Rainbow. Studies in Literature and Language Journals vol. 1 No. 4 PP 56-61

Damono, Sapardi Djoko.2000. Ayat-Ayat Api: Kumpulan Sajak. Jakarta: Pustaka Firdaus 1993. Mata Pisau. Jakarta: Balai Pustaka. Dita, Shirley N. 2010. A Stylistic Analysis of Montage. Asia Journals of English Language Studies Vol. 16 (2) 2010

Endarswara, Suwardi. 2011. Metodologi Penelitian

Sastra:Epistemologi,Mode, Teori, dan Aplikasi. Yogyakarta:

Pustaka Widyatama.

Fuadi, Ahmad. 2009. Novel Negeri 5 Menara. Bintaro.

Henni. 2010. Stylistic Analysis of Ronald Dahl's Cinderella. Proquest Journals Vol.12 No.1 Pg 42-58

Hoerip, Satyagraha. 1982. Sejumlah Masalah Sastra. Jakarta: Sinar Harapan.

Junaedi, Moha. 2000. Analisis Stilistika Pola Perkembangan Penggunaan Gaya Bahasa dalam Novel Indonesia. Jurnal Insani. Volume 4 No. 2. 